\title{
Prevalence and factors associated with Perceived stress among the general population in Pakistan during Corona-virus disease 2019
}

\section{Research Article}

Keywords: N/A

Posted Date: July 8th, 2021

DOI: https://doi.org/10.21203/rs.3.rs-601839/v2

License: (c) (1) This work is licensed under a Creative Commons Attribution 4.0 International License. Read Full License 


\section{Abstract}

The authors have requested that this preprint be withdrawn because of a duplicate submission.

\section{Full Text}

The authors have withdrawn this preprint from Research Square. 